\title{
Lipidomics and Dietary Assessment of Infant Formulas Reveal High Intakes of Major Cholesterol Oxidative Product (7-ketocholesterol)
}

Alice Kilvington $^{1}$, Carlo Barnaba ${ }^{2}$, Surender Rajasekaran ${ }^{3,4}$, Mara L. Leimanis ${ }^{3,4}$, Ilce Gabriela Medina-Meza ${ }^{1,5}$ *

${ }^{1}$ Department of Chemical Engineering and Materials Science, Michigan State University, East Lansing, MI, USA

${ }^{2}$ Institute of Quantitative Health Science and Engineering, Michigan State University, East Lansing, $M I$

${ }^{3}$ Pediatric Intensive Care Unit, Helen DeVos Children's Hospital, 100 Michigan Street NE, Grand Rapids, MI, USA

${ }^{4}$ Department of Pediatric and Human Development, College of Human Medicine, Michigan State University, East Lansing, MI

${ }^{5}$ Department of Biosystems and Agricultural Engineering, Michigan State University, East Lansing, MI, USA

*Correspondence should be directed to:

Medina-Meza Ilce Gabriela, PhD.

469 Wilson Rd.| Room 302C

East Lansing, MI

ilce@msu.edu

Phone: 517-884-1971 
medRxiv preprint doi: https://doi.org/10.1101/2020.11.18.20233528; this version posted November 20, 2020. The copyright holder for this preprint (which was not certified by peer review) is the author/funder, who has granted medRxiv a license to display the preprint in perpetuity.

It is made available under a CC-BY-NC-ND 4.0 International license .

\begin{abstract}
Approximately two-thirds of US infants receive infant formula (IF) as a primary or sole nutritional source during the first six months of life. IF is available in a variety of commercial presentations, although from a manufacturing standpoint, they can be categorized in powder- (PIF) or liquid- (LIF) based formulations. Herein, thirty commercial IFs were analyzed in their oxidative and non-oxidative lipidomics profiles. Results show that LIFs have a characteristic lipidomic fingerprint, enriched in an oxidated form of cholesterol, and a lower load of phytosterols. We identified 7-ketocholesterol - a major end-product of cholesterol oxidation - as a potential biomarker of IF manufacturing. Our data allowed re-classification of IF based on their metabolomic fingerprint, resulting in three groups assigned with low-to-high oxidative status. Finally, we modeled the dietary intake for cholesterol, sterols, and 7-ketocholesterol in the first year of life. The database provided in this study will be instrumental for scientists interested in infant nutrition, to establish bases for epidemiological studies aimed to find connections between nutrition and diet-associated diseases, such as sitosterolemia.
\end{abstract}

Keywords: Infant formula; cholesterol oxidation products; 7-ketochosterol, infant nutrition; dietary assessment, lipidomics 
medRxiv preprint doi: https://doi.org/10.1101/2020.11.18.20233528; this version posted November 20, 2020. The copyright holder for this preprint (which was not certified by peer review) is the author/funder, who has granted medRxiv a license to display the preprint in perpetuity.

It is made available under a CC-BY-NC-ND 4.0 International license .

\section{Introduction}

Today, several types of infant formula (IF) are available to meet the specific nutritional demands of infants. Soy formulas, hypoallergenic formulas, enriched formulas, hungry formulas, goat milk formulas, good night milk are some examples of the wide variety of commercial IF presentations. In the United States (U.S.), the main categories of IF are cow's milkbased, soy-based (for galactosemia), gentle/lactose-reduced (for gastrointestinal issues), and specialty (for more specific issues like phenylketonuria, fat malabsorption, or pre-term) (Maldonado, Gil, Narbona, \& Molina, 1998; Martin, Ling, \& Blackburn, 2016; Rossen, Simon, \& Herrick, 2016; Traves, 2015). The U.S. Special Supplemental Nutrition Program for Women, Infants, and Children (WIC) provides IF for $50 \%$ of all US infants and $87 \%$ of infants on WIC (Choi, Ludwig, Andreyeva, \& Harris, 2020). Approximately $75 \%$ of infants in the US receive IF as primary or sole nutrition source during the first six months of life (Harris \& Pomeranz, 2020).

IF is the gold standard of breastmilk substitutes for infants, and it must contain all the essential nutrients to supply infant needs.

We know from a recent review, that infant metabolites in a healthy population differ based on nutritional intake (M. L. L. Laurens, Kraus-Friedberg, C., Kar, W., Sanfilippo, D., Rajasekaran, S., Comstock, S. S., 2020). Premature infants or sick infants in the intensive care units of hospitals are often fed using IF (M. L. L. Laurens et al., 2020). These patients have weakened immunity from the absence of human milk (Garofalo, 2010; Hassiotou et al., 2013; Horta, Victora, \& Organization, 2013; Howie, Forsyth, Ogston, Clark, \& Florey, 1990); a developed digestive system and are vulnerable to dietary complications (Santana et al., 2017), due to lower gastric pH (Ouellet, Bailey, \& Samson, 2015), or in cases where steroids are used (Group., 1991; Lacroix, Infanterivard, Gauthier, Rousseau, \& Vandoesburg, 1986). 
medRxiv preprint doi: https://doi.org/10.1101/2020.11.18.20233528; this version posted November 20, 2020. The copyright holder for this preprint (which was not certified by peer review) is the author/funder, who has granted medRxiv a license to display the preprint in perpetuity.

It is made available under a CC-BY-NC-ND 4.0 International license .

Generally, IF is available in two presentations: liquid and powder. Manufacturing of powdered IF (PIF) includes thermal treatments, evaporation, emulsification, pasteurization, sterilization, and spray drying (Gil \& Valverde, 1985) to ensure microbial safety and shelf-life. However, exposure to high temperatures (from $170^{\circ} \mathrm{C}$ to $250^{\circ} \mathrm{C}$ during processing), light, metal ions, and shear stress among others promotes oxidation reactions, inducing undesirable changes in the product quality (Jiang \& Guo, 2014; Kilvington, Maldonado-Pereira, Torres-Palacios, \& Medina-Meza, 2019). PIF is usually stored in aluminum cans and vacuum sealed with nitrogen until the consumer first opens it. Liquid IF (LIF) can be either concentrated (needs to be mixed with water before consumption) or ready-to-feed, where sterilization is with high temperatures, followed by aseptic packaging (to guarantee microbial safety). Given its manufacturing, IF is nowadays classified as an Ultra-processed food (UPF) according to the NOVA classification (not acronyms, a name per se), which classifies food products according to their extent and purpose of industrial processing (Monteiro et al., 2019; Steele et al., 2016).

In IF approximately $45-50 \%$ of the calories come from fat, $8-12 \%$ from protein, and 40 45\% from carbohydrates (Joeckel \& Phillips, 2009). Several bioactive molecules are contained in the lipid fraction such as fatty acid, liposoluble vitamins, and phytosterols (PS). Typically plantbased oils are the major source of fat in IF, mixtures of soy, coconut, palm, safflower, or sunflower are common, being $\beta$-sitosterol and campesterol the most common PS found in IF (Hageman, Danielsen, Nieuwenhuizen, Feitsma, \& Dalsgaard, 2019; J. Wang, Bertholet, Ducret, \& Fleith, 2000). Because of this, IF contains higher amounts of PS than cholesterol. A recent study has shown that both sitosterol and 7 $\beta$-hydroxysitosterol can cross the blood-brain barrier (Schött et al., 2015). Bovine milk is the most common source of cholesterol in IF with an average of $15-50 \mathrm{mg} / \mathrm{L}$ (Babawale et al., 2018). Cholesterol is essential especially during the rapid growth of infants. In 
medRxiv preprint doi: https://doi.org/10.1101/2020.11.18.20233528; this version posted November 20, 2020. The copyright holder for this preprint (which was not certified by peer review) is the author/funder, who has granted medRxiv a license to display the preprint in perpetuity.

It is made available under a CC-BY-NC-ND 4.0 International license .

addition, fatty acids are other important bioactive lipids, which are essential to forming the brain membrane and myelin (Georgieff \& Rao, 2001). Particularly, docosahexaenoic acid (DHA) and arachidonic acid (AA) have been shown to be critical for cognitive, health and development during gestation and early postnatal life; as a result, DHA and AA are often supplemented in IF (Lorenzo et al., 2019).

Lipid oxidation is a natural process that occurs in presence of initiators which may determine the extent of the oxidative process. Usually, malondialdehyde (MDA) is one of the major auto-oxidation products of lipids and so it is commonly used as a biomarker of lipid peroxidation (Botsoglou et al., 1994; Cesa, 2004; Nielsen, Olsen, Jensen, \& Skibsted, 1996). Lipid oxidized products have been shown to be harmful to human health (Pozzo et al., 2019; Zmyslowski \& Szterk, 2019). MDA, the product of fatty acid oxidation, is suspected to be a carcinogen and lead to mutations (Abela et al., 2019; Griffiths et al., 2016; Kulig, Cwiklik, Jurkiewicz, Rog, \& Vattulainen, 2016).

Addition of polyunsaturated fatty acids (PUFA), iron for IF fortification, and antioxidants increase the sensitivity to oxidation, allowing the generation of oxidized compounds such as cholesterol oxidation products (COPs) (Calderon-Santiago, Peralbo-Molina, Priego-Capote, \& de Castro, 2012; Maldonado-Pereira, Schweiss, Barnaba, \& Medina-Meza, 2018; Medina-Meza \& Barnaba, 2013), and MDA derivatives (Cesa, 2004). COPs have been linked to atherosclerosis, hypertension, ischemic stroke, neurological diseases, viral infections, and cancer (Testa, Rossin, Poli, Biasi, \& Leonarduzzi, 2018; Willinger, 2019; Zmyslowski \& Szterk, 2019). In IF, the evaluation of lipid peroxidation and exposure to oxidized compounds have been focused mainly on adults' diet; however, IF as UPF may possess a larger number of oxidized compounds and the 
medRxiv preprint doi: https://doi.org/10.1101/2020.11.18.20233528; this version posted November 20, 2020. The copyright holder for this preprint (which was not certified by peer review) is the author/funder, who has granted medRxiv a license to display the preprint in perpetuity.

It is made available under a CC-BY-NC-ND 4.0 International license .

adverse effects on an infant's health is still unknown. Considering health risks associated with oxidized lipids intake, the oxidative load on IF should be studied.

In this study, we performed a large-scale study on the oxidative status of IF. Thirty commercial products were collected and their lipidomic profiles were assessed, with particular attention to oxidized cholesterols and oxidative markers. To the best of the authors' knowledge, ours is the first study that provides a vast lipidomic analysis in a large set of commercial formulas. We confirm that 7-ketocholesterol is a biomarker for formula manufacturing and a potential biomarker of IF consumption through dietary exposure model. Based on our lipidomic dataset, a dietary intake assessment was performed for the 7-ketocholesterol biomarker, as well as overall oxidative load. Finally, we regroup the formulas according to their oxidative status using a clustering algorithm, overcoming the limitation of labeling attributes with a more rigorous metabolomic-based classification approach. The presented results will serve as a guide and data reference for consumers, pediatricians, clinicians, and scientists interested in infant diet and development.

\section{Materials and Methods}

\section{Chemicals}

Diethyl ether, ethanol, chloroform, methanol, hexane, ethyl acetate, isopropyl alcohol, acetone, sulfuric acid, sodium sulfate, potassium hydroxide, sodium chloride, campesterol, tocopherols, stigmasterol, squalene, $\beta$-sitosterol, and Supelco 37 FAME mix were purchased from Sigma Aldrich (St Louis, MO). Cholesterol, fucosterol, brassicasterol, lanosterol, $5 \alpha$-cholestane, 19-hydroxycholesterol, and the cholesterol oxidation products (COPs) standards were purchased from Steraloids Inc. (Newport, Rhode Island). 
medRxiv preprint doi: https://doi.org/10.1101/2020.11.18.20233528; this version posted November 20, 2020. The copyright holder for this preprint (which was not certified by peer review) is the author/funder, who has granted medRxiv a license to display the preprint in perpetuity.

It is made available under a CC-BY-NC-ND 4.0 International license .

\section{Infant formulas sample set}

A total of thirty IF both powder and liquid were purchased from local supermarkets and/or online through the manufacturer's website, covering a broad variety of nutrition requirements for infants, and commonly used in a hospital setting. The nutritional contents of the IF as indicated in the label is presented in Table S1.

\section{Lipid extraction}

Lipids were extracted using the Folch method (Folch, Lees, \& Sloane-Stanley, 1957) with a few modifications. Briefly, IF powders were solubilized in water according to the directions on the label. One scoop (9 grams) of powder was mixed with $30 \mathrm{~mL}$ of tap water to emulate the common preparation for consumption. The extraction of the lipid fraction was done with 8:1 solution of diethyl ether: ethanol. After phase separation, lipid fraction was recovered, dried under $\mathrm{N}_{2}$ stream, resuspended in 4:1 hexane: isopropyl alcohol, and stored at $-20^{\circ} \mathrm{C}$ for further analysis. A similar procedure was used with the ready-to-eat LIF; however, due to the excessive water being collected in the lipid fraction, methanol was used instead of ethanol and chloroform was used instead of diethyl ether for extraction. We did not observe any difference in fat yield extraction by changing the solvents mixture. LHF3, a concentrated liquid formula, had to be diluted 1:1 with water before the Folch procedure.

\section{Total sterols profiling by GC-MS}

Two hundred mg of fat were placed into a glass tube and dried under a nitrogen stream. 40 ug of $5 \alpha$-cholestane $(5 \alpha)$ and 50 ug of 19-hydroxycholesterol (19-OH) were added as internal standards. Ten $\mathrm{mL}$ of $1 \mathrm{~N}$ methanolic $\mathrm{KOH}$ were added and vortexed. The unsaponifiable fraction was collected and sodium sulfate was added. The mixture was left standing for 2 hours and then filtered over a bed of sodium sulfate and collected in a round bottom flask. The solution was then 
medRxiv preprint doi: https://doi.org/10.1101/2020.11.18.20233528; this version posted November 20, 2020. The copyright holder for this preprint (which was not certified by peer review) is the author/funder, who has granted medRxiv a license to display the preprint in perpetuity.

It is made available under a CC-BY-NC-ND 4.0 International license .

dried in a vacuum evaporator. The sterols were then collected in diethyl ether and dried with a stream of nitrogen. One $\mathrm{mL}$ of 4:1 hexane: isopropanol was added and then stored at $-20^{\circ} \mathrm{C}$ until analysis. One-hundred microliters $(\mu \mathrm{L})$ were derivatized by drying with nitrogen and adding 100 $\mu \mathrm{L}$ of pyridine and $100 \mu \mathrm{L}$ of silanization solution and then heated at $60^{\circ} \mathrm{C}$ for $40 \mathrm{~min}$. The solution was then dried and resuspended in $200 \mu \mathrm{L}$ hexane. Two $\mu \mathrm{L}$ were injected into a GC coupled to a MS (GC-MS) (Shimadzu GCMS-QP 2010 SE, LabSolutions GCMS Solution Version 4.45). Injector temperature was set at $320^{\circ} \mathrm{C}$. The oven temperature profile was programmed to start at $260^{\circ} \mathrm{C}$ and increase to $300^{\circ} \mathrm{C}$ at a rate of $2.5^{\circ} \mathrm{C} / \mathrm{min}$, then from $300^{\circ} \mathrm{C}$ to $320^{\circ} \mathrm{C}$ at a rate of $8^{\circ} \mathrm{C} / \mathrm{min}$ and held for 1 min. Helium was used as a carrier gas with a pressure of $134 \mathrm{kPa}$. The sterol identification was done by comparing retention times and mass fragmentations from pure standards. Quantification was done by comparing peak areas using the internal standards.

\section{Sterols oxidation products profiling by $G C-M S$}

The remaining $900 \mu \mathrm{L}$ of the unsaponifiable fat were enriched in the sterol oxidation products by solid-phase extraction (SPE), using $\mathrm{NH}_{2}$ Strata ${ }^{\circledR} \mathrm{SPE}$ cartridge. Enriched samples were dried using a nitrogen stream and then derivatized as described above. First, the samples were analyzed using the Total Ion Chromatogram (TIC) method. Two $\mu \mathrm{L}$ of the sample were injected into a GC coupled to a MS (GC-MS) (Shimadzu GCMS-QP 2010 SE, LabSolutions GCMS Solution Version 4.45). The injector temperature was set to $320^{\circ} \mathrm{C}$. The oven temperature profile was programmed from $260^{\circ} \mathrm{C}$ to $280^{\circ} \mathrm{C}$ at a rate of $2^{\circ} \mathrm{C} / \mathrm{min}$ and held for $7 \mathrm{~min}$ and then from $280^{\circ} \mathrm{C}$ to $315^{\circ} \mathrm{C}$ at a rate of $1.5^{\circ} \mathrm{C} / \mathrm{min}$. Identification of compounds was performed using retention times and mass fragmentations from commercial standards. Using the TIC method, the quantification of the total sterols content was done by comparing the peak areas to the internal standard, 19-OH. The Selected Ion Monitoring (SIM) method was used to profile the COPs in the 
medRxiv preprint doi: https://doi.org/10.1101/2020.11.18.20233528; this version posted November 20, 2020. The copyright holder for this preprint (which was not certified by peer review) is the author/funder, who has granted medRxiv a license to display the preprint in perpetuity.

It is made available under a CC-BY-NC-ND 4.0 International license .

IF. The injector temperature was set to $320^{\circ} \mathrm{C}$. The oven temperature profile was programmed from $260^{\circ} \mathrm{C}$ to $280^{\circ} \mathrm{C}$ at a rate of $2.0^{\circ} \mathrm{C} / \mathrm{min}$ and held for $7 \mathrm{~min}$ and then from $280^{\circ} \mathrm{C}$ to $315^{\circ} \mathrm{C}$ at a rate of $1.5^{\circ} \mathrm{C} / \mathrm{min}$. Helium was used as a carrier gas with a pressure of $49.2 \mathrm{kPa}$ and a column flow rate of $0.41 \mathrm{~mL} / \mathrm{min}$. The ion source temperature for the $\mathrm{MS}$ was set at $230^{\circ} \mathrm{C}$. Identification of compounds was done using retention times and mass fragmentations from commercial standards.

\section{Fatty acid methyl esters profiling (FAME)}

FAME samples were prepared according to Chen et al. (Chen, Aluwi, Saunders, Ganjyal, \& Medina-Meza, 2019). Twenty milligrams (mg) of fat were placed into a test tube. Tridecanoic acid was used as an internal standard. Briefly, $0.5 \mathrm{~N} \mathrm{NaOH}$ in methanol was added to the samples, heated for $15 \mathrm{~min}$ at $105^{\circ} \mathrm{C}$, and then cooled on ice for one minute. Boron trifluoride was added and samples were heated for $15 \mathrm{~min}$, following by rapid cooling in an ice bath. One $\mathrm{mL}$ of hexane and $2 \mathrm{~mL}$ of $2 \mathrm{M} \mathrm{NaCl}$ were added to the samples and then shaken vigorously. The methylated fraction was collected and diluted 200 -fold. One $\mu \mathrm{L}$ was injected into a gas chromatograph coupled with flame ionization detector (GC-FID) (Shimadzu GC-2010, Kyoto, Japan). The injector temperature was set at $250^{\circ} \mathrm{C}$. The oven temperature started at $120^{\circ} \mathrm{C}$ and increased to $200^{\circ} \mathrm{C}$ at a rate of $3.5^{\circ} \mathrm{C} / \mathrm{min}$, then further increased to $240^{\circ} \mathrm{C}$ at a rate of $1.5^{\circ} \mathrm{C} / \mathrm{min}$ and then was held for 2 min. Helium was used as carrier gas with a pressure of $92.2 \mathrm{kPa}$ and a total flow rate of $5.9 \mathrm{~mL} / \mathrm{min}$. Identification was done by comparison of retention times of FAME standards (FAME Supelco 37 mixture Sigma Aldrich). A standard curve with 500, 200, 100, 50, and $25 \mu \mathrm{g} / \mathrm{mL}$ concentrations were used for quantification. 
medRxiv preprint doi: https://doi.org/10.1101/2020.11.18.20233528; this version posted November 20, 2020. The copyright holder for this preprint (which was not certified by peer review) is the author/funder, who has granted medRxiv a license to display the preprint in perpetuity.

It is made available under a CC-BY-NC-ND 4.0 International license .

\section{Oxidative status (TBARS)}

The thiobarbituric acid reactive substances (TBARS) assay was performed following a modified version of Miller's protocol (Miller, 1998). Sixty mg of fat from the infant formulas were placed into a test tube. One-hundred $\mu \mathrm{L}$ of butylated hydroxytoluene was added to each sample. One set of replicates was spiked with 1,1,3,3-tetraethoxypropane (TEP) to confirm the reaction was occurring. Then, 10\% tricholoroacetic acid (TCA) in phosphoric acid solution was added. Samples were mixed and then split into two aliquots. One aliquot was mixed with deionized water to be used as a blank and the other aliquot was mixed with thiobarbituric acid (TBA). Samples were left overnight in a dark cabinet. Standards of $0.5,1.0,1.5,2.0 \mathrm{~mL}$ TEP were mixed with TCA and TBA and leftover night to be used as a calibration curve. Absorbance was recorded with a UV-Vis Double Beam Spectrophotometer UV-6300PC (VWR, Radnor, PA) at $530 \mathrm{~nm}$. Quantification was achieved by comparing the sample absorbances with the calibration curve, and results expressed as $\mathrm{mg}$ of $\mathrm{MDA} / \mathrm{g}$ fat.

\section{Total antioxidant capacity (To $A C)$}

The ToAC was performed according to Khan and co-workers (Khan et al., 2017). Briefly, $3 \mathrm{~mL}$ of $0.6 \mathrm{M}$ sulfuric acid, $3 \mathrm{~mL}$ of $4 \mathrm{mM}$ ammonium molybdate, and $3 \mathrm{~mL}$ of $28 \mathrm{mM}$ sodium phosphate was added to $0.3 \mathrm{~mL}$ of IF. The test tubes were incubated at $85^{\circ} \mathrm{C}$ for $90 \mathrm{~min}$. After cooling to room temperature, the mixture was centrifuged, and the supernatant was placed into a glass cuvette and read using a UV-Vis Double Beam Spectrophotometer UV-6300PC (VWR, Radnor, PA) at $695 \mathrm{~nm}$. Results were reported as mg equivalents of ascorbic acid/L.

\section{Protein}

Two-hundred and fifty mg of IF was used to determine the protein content by using a LECO Nitrogen Analyzer FP828. The method used was provided by LECO with coordination from the 
medRxiv preprint doi: https://doi.org/10.1101/2020.11.18.20233528; this version posted November 20, 2020 . The copyright holder for this preprint (which was not certified by peer review) is the author/funder, who has granted medRxiv a license to display the preprint in perpetuity.

It is made available under a CC-BY-NC-ND 4.0 International license .

Application Specialist to be optimized for the IF matrix. EDTA was used as a standard to calibrate the machine, and helium was used as a carrier gas. The furnace was set to $950^{\circ} \mathrm{C}$ and the afterburner was set at $850^{\circ} \mathrm{C}$. The furnace flow was set to $5 \mathrm{~L} / \mathrm{min}$ for 30 seconds, then $1 \mathrm{~L} / \mathrm{min}$ for 30 seconds, and then $5 \mathrm{~L} / \mathrm{min}$. The standard protein factor of 6.38 was used to obtain protein content.

\section{Dietary intake}

A dietary intake (DI) assessment spanning the first 12 months of infant life was performed. The DI for the first six months was calculated based on the energetic requirements (Food and Agriculture Organization, 2004), assuming a 100\% formula diet. At 6 months, infants are introduced to solid food according to USDA guidelines, thus from 6 to 12 months an average IF supplement to a solid diet was used (USDA, 2018). 7-ketocholesterol, Total COPs, Total Phytosterols, and Total Sterols intakes were assessed using mean and the $95 \%$ confidence interval

(Table 1). The model used for calculating the DI was the following:

$$
D I=\frac{[C] * \text { intake } * A b s}{B W}
$$

Where DI is the dietary intake ( $\mathrm{mg} \mathrm{kg}^{-1}$ of body weight $\mathrm{d}^{-1}$ ), $[C]$ is the concentration of the compounds ( $\mathrm{mg} \mathrm{mL}^{-1}$ of formula, as liquid or prepared from powder), intake is the average daily formula intake during the specific growth period $\left(\mathrm{mL} \mathrm{d}^{-1}\right), A b s$ is the coefficient of absorption of the considered compounds, and $B W$ is the average body weight of infants during the specific growth period $(\mathrm{kg})$. There is no consensus on the $A b s$ percentage of COPs and sterols. For the parent cholesterol, ranges from 20 to 80\% have been published (Ogino et al., 2007; Vine, Croft, Beilin, \& Mamo, 1997), with 60-70\% being the most reported. For phytosterols, higher absorption than cholesterol has been reported (Grandgirard, Sergiel, Nour, Demaison-Meloche, \& Gihiès, 1999; Liang et al., 2011; M. M. Wang \& Lu, 2018), although results are controversial. Herein, we opted for a conservative 0.5 coefficient. The average $B W$ for infants was obtained from the 
medRxiv preprint doi: https://doi.org/10.1101/2020.11.18.20233528; this version posted November 20, 2020. The copyright holder for this preprint (which was not certified by peer review) is the author/funder, who has granted medRxiv a license to display the preprint in perpetuity.

It is made available under a CC-BY-NC-ND 4.0 International license .

literature (De Onis \& Onyango, 2008); 50 ${ }^{\text {th }}$ percentile of weight was used. We found no appreciable differences between female and male dietary intake; thus, data were averaged between sexes.

\section{Statistical analysis}

A one-way ANOVA (95\% significance level) was performed to statistically evaluate the chemical responses across the different formulations; Pearson correlation across variables was also tested. Variables expressed as percentage (i.e. protein) were arcsine square root transformed (Olson, 1976). Before variable reduction analysis, the dataset was normalized by sum, mean centered, auto scaled, and the normal distribution verified (Wanichthanarak, Fan, Grapov, Barupal, \& Fiehn, 2017). ANOVA-based heatmap and biomarker analysis, including the ROC curves, were performed using MetaboAnalyst in its web server version (Chong et al., 2018; Xia \& Wishart, 2016). The transformed data were subjected to Factor Analysis to reduce the variables to a set of new orthogonal variables retaining $>70 \%$ of the variance across the samples. Before Factor Analysis, data adequacy was assessed by the Kaiser-Meyer-Olkin (KMO) test (Kaiser, 1974), and variables having KMO a value $<0.5$ were excluded and factor analysis repeated until the overall KMO value was 0.6 or higher. Factor analysis was performed using the Principal Components Analysis algorithm. Identification of the minima number of PCs was achieved by cumulative variance and direct visualization of the scree plot (Cadima \& Jolliffe, 1995). The first five components, representing $\sim 73 \%$ of the cumulative variance, were used for subsequent cluster analysis. The $k$-means clustering algorithm was performed using the hierarchical Ward's criterion (minimum variance method); distance between clusters was computed using the Euclidean algorithm. PCA's eigenvalues were visualized using a heatmap algorithm. ANOVA, Pearson 
medRxiv preprint doi: https://doi.org/10.1101/2020.11.18.20233528; this version posted November 20, 2020. The copyright holder for this preprint (which was not certified by peer review) is the author/funder, who has granted medRxiv a license to display the preprint in perpetuity.

It is made available under a CC-BY-NC-ND 4.0 International license .

correlation, KMO test were computed using SPSS (IBM). PCA and $k$-means clustering were performed in OriginPro (OriginLab, v.2020).

\section{RESULTS}

Overall metabolite and oxidative status assessment. We performed fat and protein quantification to determine if our findings matched the information contained in the product label (Table S2 in Supplemental information). The total fat recovered after extraction from the LIF was much closer to the label compared to PIF ( $14 \%$ vs. $28 \%$ difference on average). LIFs have significant lower protein content than PIF $(p<0.01)$. Compared to the amount reported in the label, our results underestimated the protein content on an average of $27 \%$; the difference between the reported value and our findings were $36 \%$ and $18 \%$ for PIF and LIF, respectively. The correlation between label and measured protein content was high in PIF $(R=0.93)$, but poor in LIF $\left(R^{2}=0.34\right)$. The reason for such difference between label and measured data can be attributed to several factors, including the method and/or equipment used for quantifying protein. The liquid formulations used in this study came in different presentation (ready-to-fed, concentrated), thus the preparation of sample prior to analysis can be an additional source of analytical error. When compared to literature, the results for both fat and protein align (Koletzko, 2009; Lorenzo et al., 2019; Saxena et al., 2019).

Lipidomics showed a higher amount of total phytosterols in the PIF than the LIFs, with an average of $3.33(2.77-3.89,95 \% \mathrm{CI}) \mathrm{mg} / \mathrm{scoop}$ and $1.95(1.64-2.26) \mathrm{mg} / \mathrm{scoop}$, respectively. Cholesterol was found with an average content $1.60(1.11-2.08) \mathrm{mg} / \mathrm{scoop}$, followed by $\beta$-sitosterol with $0.67(0.59-0.76) \mathrm{mg} / \mathrm{scoop}$, campesterol $0.46(0.38-0.55) \mathrm{mg} / \mathrm{scoop}$, desmosterol $0.23(0.21-$ $0.26) \mathrm{mg} / \mathrm{scoop}$, fucosterol $0.14(0.11-0.17) \mathrm{mg} / \mathrm{scoop}$, and stigmasterol $0.13(0.11-0.14)$ 
$\mathrm{mg} / \mathrm{scoop}$. Comparison with previous literature is difficult, due to the lack of large datasets, and the units of quantitative measurement. Two studies on IF estimated the total sterol concentration to be in the range of 6.5-15.2 mg/100 mL reconstituted IF (G. García-Llatas et al., 2008; Hamdan, Sanchez-Siles, Garcia-Llatas, \& Lagarda, 2018). Comparatively, we found total sterol concentrations of $6.46 \pm 1.64 \mathrm{mg} / 100 \mathrm{~mL}$ of sample and $11.08 \pm 2.11 \mathrm{mg} / 100 \mathrm{~mL}$ of IF liquid and powder, respectively. In contrast, cholesterol concentrations in IF may vary between 0.1 to 7.3 mg/g lipid (Scopesi et al., 2002; Zunin, Calcagno, \& Evangelisti, 1998). Our results range from 0.3 to $2.14 \mathrm{mg}$ of cholesterol per g of lipid (Table S3, Supplemental information).

Regarding bioactive lipids with antioxidant properties, we found tocopherols. $\alpha-, \beta-, \gamma-$, and $\delta$-tocopherols belong to the vitamin E class of compounds. These compounds are known for their radical scavenging properties, for protecting against chromosome damage, lipid peroxidation, and DNA oxidation (Li, Cherian, Ahn, Hardin, \& Sim, 1996). Tocopherols are usually added to IF to increase vitamin content and prevent lipid oxidation during processing and storage, extending the product's shelf-life (Miquel, Alegria, Barbera, Farre, \& Clemente, 2004). Total tocopherols range from 0.07 to $0.71 \mathrm{mg} / \mathrm{scoop}$ in PIF and from 0.054 to $0.33 \mathrm{mg} /$ serving in LIF (Table S4 Supplemental material). Overall, PIF contained higher amounts of tocopherol compared to LIF ( $p$ $<0.05$, Table 1), with the $\gamma$-tocopherol being 5 -fold higher in powder formulations. These results agree with Lee et al. (Lee, Jang, \& Kim, 2013) and Miquel et al (Miquel et al., 2004) for powder IF and contrast with Dorota et al. (Martysiak-Zurowska, Szlagatys-Sidorkiewicz, \& Zagierski, 2013) for liquid IF. These differences may be accounted to the type of formula used (a specific follow-up IF), as well as manufacturing. Little information has been reported for COPs and their metabolites in IF (Scopesi et al., 2002). 7 $\alpha$-hydroxycholesterol (7 $\alpha-\mathrm{OH}), 7 \beta$-hydroxycholesterol (7 $\beta$-OH), 7-ketocholesterol (7-keto), $\quad 5 \alpha, 6 \alpha$-epoxycholesterol $\quad(5,6 \alpha$-epoxy), $\quad 5 \beta, 6 \beta-$ 
medRxiv preprint doi: https://doi.org/10.1101/2020.11.18.20233528; this version posted November 20, 2020. The copyright holder for this preprint (which was not certified by peer review) is the author/funder, who has granted medRxiv a license to display the preprint in perpetuity.

It is made available under a CC-BY-NC-ND 4.0 International license .

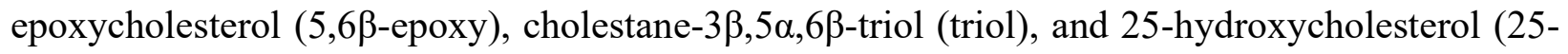

OH) (Gorassini, Verardo, Fregolent, \& Bortolomeazzi, 2017; Guardiola, Bou, Boatella, \& Codony,

2004; Rodriguez-Estrada, Garcia-Llatas, \& Lagarda, 2014) and 7-ketocholesterol are the most

common COPs found in foods (Zunin et al., 1998).

Table 1. Content of fat, steroidal compounds, fatty acids, and redox values for in IF. Data are expressed as $\mathrm{mg} / \mathrm{serving}$ except where indicated. Average and the $95 \%$ confidence interval is reported for the whole dataset (IF, $n=30$ ) and powder (PIF, $n=15$ ) and liquid (LIF $n=15$ ) categories. $t$-test significance assessment between PIF and LIF is indicated. "Sum of steroids from animal origin. ${ }^{\ddagger}$ Sum of phytosterols.

\begin{tabular}{|c|c|c|c|c|}
\hline & IF & PIF & LIF & $\begin{array}{l}t \text {-test (PIF vs. } \\
\text { LIF) }\end{array}$ \\
\hline Protein $(g /$ serving $)$ & $1.9(1.7-2.1)$ & $1.6(1.5-1.7)$ & $2.2(1.7-2.6)$ & $* * *$ \\
\hline Total fat ( $g /$ serving) & $2.57(2.41-2.74)$ & $2.71(2.47-2.96)$ & $2.43(2.20-2.66)$ & \\
\hline \multicolumn{5}{|l|}{ Sterols } \\
\hline Cholesterol & $1.60(1.11-2.08)$ & $1.34(0.57-2.11)$ & $1.94(1.14-2.74)$ & \\
\hline Desmosterol & $0.23(0.21-0.26)$ & $0.26(0.21-0.31)$ & $0.21(0.18-0.23)$ & \\
\hline Stigmasterol & $0.13(0.11-0.14)$ & $0.14(0.12-0.16)$ & $0.11(0.01-0.13)$ & * \\
\hline$\beta$-sitosterol & $0.67(0.59-0.76)$ & $0.81(0.71-0.92)$ & $0.53(0.43-0.63)$ & $* * *$ \\
\hline Campesterol & $0.46(0.38-0.55)$ & $0.60(0.48-0.72)$ & $0.33(0.27-0.38)$ & $* * *$ \\
\hline Fucosterol & $0.14(0.11-0.17)$ & $0.18(0.14-0.22)$ & $0.11(0.08-0.13)$ & $* *$ \\
\hline Total Sterols & $1.87(1.33-2.40)$ & $1.60(0.83-2.37)$ & $2.13(1.33-2.93)$ & \\
\hline Total Phytosterols ${ }^{\ddagger}$ & $2.64(2.24-3.04)$ & $3.33(2.77-3.89)$ & $1.95(1.64-2.26)$ & $* * *$ \\
\hline \multicolumn{5}{|l|}{ Tocopherols } \\
\hline$\beta$-tocopherol & $\begin{array}{c}0.019(0.011- \\
0.027)\end{array}$ & $\begin{array}{c}0.014(0.008- \\
0.021)\end{array}$ & $\begin{array}{c}0.024(0.009- \\
0.039)\end{array}$ & \\
\hline$\gamma$-tocopherol & $\begin{array}{c}0.019(0.011- \\
0.027)\end{array}$ & $\begin{array}{c}0.033(0.023- \\
0.043)\end{array}$ & $\begin{array}{l}0.006(0.002- \\
0.013)\end{array}$ & $* * *$ \\
\hline$\alpha$-tocopherol & $\begin{array}{c}0.044(0.031- \\
0.057)\end{array}$ & $\begin{array}{c}0.032(0.020- \\
0.043)\end{array}$ & $\begin{array}{c}0.056(0.033- \\
0.078)\end{array}$ & \\
\hline Total Tocopherols & $0.22(0.17-0.28)$ & $0.28(0.18-0.38)$ & $0.17(0.11-0.22)$ & * \\
\hline Squalene & $\begin{array}{c}0.059(0.036- \\
0.082) \\
\end{array}$ & $\begin{array}{c}0.060(0.025- \\
0.10)\end{array}$ & $\begin{array}{c}0.060 \\
(0.0240 .092) \\
\end{array}$ & \\
\hline \multicolumn{5}{|l|}{ COPs $(\mu g /$ serving $)$} \\
\hline $7 \alpha$-hydroxycholesterol ( $7 \alpha-\mathrm{OH})$ & $5.20(3.68-6.71)$ & $4.22(2.67-5.78)$ & $6.17(3.43-8.89)$ & \\
\hline $7 \beta$-hydroxycholesterol $(7 \beta-\mathrm{OH})$ & $6.75(4.54-8.95)$ & $5.24(2.70-7.78)$ & $8.25(4.50-12.02)$ & \\
\hline 7-ketocholesterol (7-keto) & $1.42(0.94-1.89)$ & $1.97(1.20-2.75)$ & $0.86(0.39-1.33)$ & ** \\
\hline 25-hydroxycholesterol (25-OH) & $0.94(0.31-1.58)$ & $1.09(0.51-1.65)$ & $0.81(-0.42-2.03)$ & \\
\hline 3,5,6-cholestan-triol (triol) & $1.12(0.79-1.44)$ & $1.29(0.70-1.87)$ & $0.95(0.62-1.28)$ & \\
\hline 6-ketocholestenol (6-keto) & $\begin{array}{l}1.07(-0.01- \\
2.16)\end{array}$ & $\begin{array}{l}1.95(-0.26- \\
4.15)\end{array}$ & $0.20(0.06-0.33)$ & \\
\hline $\begin{array}{c}5 \beta, 6 \beta \text {-epoxycholesterol }(5,6 \beta- \\
\text { epoxy) }\end{array}$ & $0.21(0.13-0.29)$ & $0.22(0.10-0.34)$ & $0.20(0.07-0.33)$ & \\
\hline $\begin{array}{c}5 \alpha, 6 \alpha \text {-epoxycholesterol }(5,6 \alpha- \\
\text { epoxy) }\end{array}$ & $0.17(0.08-0.27)$ & $0.24(0.05-0.44)$ & $0.11(0.05-0.16)$ & \\
\hline Total COPs & $19.2(12.3-26.1)$ & $16.8(10.9-22.7)$ & $21.6(8.3-34.9)$ & $*$ \\
\hline
\end{tabular}




\begin{tabular}{ccccc} 
C8 & $8.6(5.6-11.7)$ & $3.3(0.8-5.9)$ & $6.9(3.2-10.5)$ & \\
C10 & $5.6(3.9-7.2)$ & $2.7(0.8-4.5)$ & $5.6(2.7-8.6)$ & $* *$ \\
C12 & $6.9(5.7-8.1)$ & $8.8(7.4-10.2)$ & $5.2(2.8-7.6)$ & $*$ \\
C14 & $3.4(2.7-4.1)$ & $4.0(3.3-4.6)$ & $2.5(1.3-3.6)$ & \\
C16 & $14.4(12.1-16.6)$ & $15.5(11.3-19.8)$ & $12.7(8.4-16.9)$ & \\
C16:1 & $0.07(0.06-0.09)$ & $0.10(0.07-0.13)$ & $0.07(0.04-0.09)$ & \\
C18 & $3.9(3.6-4.2)$ & $3.7(3.3-4.2)$ & $4.7(4.1-5.4)$ & \\
C18:1cis & $32.0(28.8-35.1)$ & $36.9(34.6-39.1)$ & $39.3(37.6-41.0)$ & \\
C18:2cis & $21.4(19.7-23.2)$ & $21.2(19.7-22.7)$ & $19.5(18.2-20.8)$ & \\
C18:3n6 & $2.3(2.1-2.5)$ & $2.3(2.1-2.5)$ & $2.0(1.8-2.2)$ & \\
C20 & $0.25(0.22-0.27)$ & $0.29(0.27-0.31)$ & $0.31(0.27-0.34)$ & \\
C20:1 & $0.11(0.09-0.13)$ & $0.13(0.12-0.15)$ & $0.15(0.11-0.19)$ & \\
C20:3n6 & $0.59(0.52-0.66)$ & $0.48(0.41-0.55)$ & $0.55(0.45-0.64)$ & \\
C20:5 & $0.21(0.18-0.25)$ & $0.18(0.15-0.21)$ & $0.22(0.15-0.30)$ & \\
C24 & $0.23(0.20-0.27)$ & $0.20(0.15-0.26)$ & $0.20(0.15-0.24)$ & \\
SFA (\%) & $43.3(39.1-47.4)$ & $38.3(36.0-40.7)$ & $48.2(40.7-55.8)$ & $*$ \\
MUFA (\%) & $32.1(27.6-36.7)$ & $38.3(36.3-40.4)$ & $26.0(17.8-34.1)$ & $*$ \\
PUFA (\%) & $24.6(21.9-27.2)$ & $23.3(21.8-24.8)$ & $25.8(20.5-31.1)$ & \\
\hline TBARs (ppb/serving) & $0.52(0.49-0.55)$ & $0.50(0.49-0.52)$ & $0.53(0.47-0.59)$ & \\
ToAC (mg ascorbic ac. & $7.4(4.3-10.6)$ & $10.7(5.0-16.4)$ & $4.2(1.8-6.6)$ & $*$ \\
equiv./serving) & & & \\
\hline CoPs & & & \\
\hline
\end{tabular}

COPs: Cholesterol oxidation products, TBARs: Thiobarbituric acid reactive substances, ToAc: Total Antioxidant (equivalent Ascorbic acid). SFA: saturated fatty acid, MUFA: monounsaturated fatty acid, PUFA: Polyunsaturated fatty acid.

We found an average of $16.8(10.9-22.7,95 \% \mathrm{CI}) \mu \mathrm{g} / \mathrm{scoop}$ and $21.6(8.3-34.9,95 \% \mathrm{CI}) \mu \mathrm{g} / \mathrm{scoop}$ for powder and liquid formulations, respectively, is significantly higher for LIF $(p<0.05)$. Nine

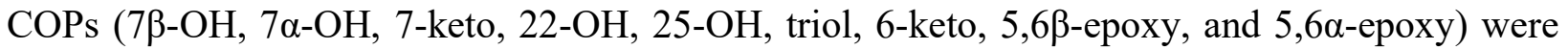
identified in the IF samples. The most abundant were the C7-hydroxy isomers 7 $\beta-\mathrm{OH}$ (average of $6.75 \mu \mathrm{g} / \mathrm{scoop}$ ) and $7 \alpha-\mathrm{OH}$ (average of $5.20 \mu \mathrm{g} / \mathrm{scoop}$ ). Garcia-Llatas et al. (G. García-Llatas et al., 2008) reported COPs found in two ready-to-eat IFs (23-28 $\mu \mathrm{g} / 100 \mathrm{~g}$ sample), which is lower than our data when adjusted to the amount of sample. We cannot exclude that this discrepancy could be due to differences in the manufacturing process between Europe and the USA (Guo, 2014). 7-keto was the third highest COPs in IF, with an average value of $1.42 \mu \mathrm{g} / \mathrm{scoop}(0.77 \mu \mathrm{g} / \mathrm{g}$ lipids for PFI and $0.49 \mu \mathrm{g} / \mathrm{g}$ lipids for LIF); our results agree with Scopessi and coworkers (Scopesi et al., 2002) who found $0.3-11.2 \mu \mathrm{g} / \mathrm{g}$ of lipid of 7-keto from a set of ten IFs . Conversely, our data is lower than that reported by others $(1.2-11.2 \mu \mathrm{g} / \mathrm{g}$ of lipids), in a study performed on six 
IF (Zunin et al., 1998). It is not possible to exclude that such discrepancies in COPs and other oxidative compounds between studies can be associated with the advancement in IF manufacturing process and formulation itself. Importantly, our data show that 7-keto is the only COPs present in significantly $(p<0.01)$ higher amount in PIF, compared to LIF.

Saturated fatty acids (SFA) made up $43 \pm 11 \%$ of the fatty acids, with C16:0 as the most abundant fatty acid in all IF, followed by $\mathrm{C} 8: 0$ and $\mathrm{C}: 10: 0$. These results are in line with previous studies, confirming that SFA\% may be a good biomarker for milk-based fat IF (Ceballos et al., 2009). Comparing formulations, LIF contained up to 2-fold higher amount of C:8 and C:10 than PIF; however, the differences were not statistically significant ( $p=0.10$ and $p=0.08$, respectively). On the contrary, C12 and C14 were slightly but significantly higher in PIF (Table 1). Monounsaturated fatty acid (MUFA) average content is $32 \pm 12 \%$ with $\mathrm{C}-18: 1$ being the most abundant fatty acid. PIF contained $\sim 45 \%$ more MUFA than LIF $(p<0.01)$, at the expenses of SFA content. It is known that oleic acid content is higher in plant-based oil source IF, due to their high content in sunflower and soybean oils. Polyunsaturated fatty acid (PUFA) content was $25 \pm 7 \%$, with $\mathrm{C} 18: 2$ as the major fatty acid followed by $\mathrm{C}: 18: 3 \mathrm{n} 6$. No significant differences were found between LIF and PIF. Many other research groups have analyzed the fatty acid profile of IF, being close to our findings (Guadalupe García-Llatas et al., 2008; Hageman et al., 2019; Romeu-Nadal, Chávez-Servín, Castellote, Rivero, \& López-Sabater, 2007). The major difference in FAME profile is the oil source, which plays a critical role in the formulation, plant-oil formula and cow's milk formula are the most common formulations followed by goat's milk IF (Sun et al., 2016). 
medRxiv preprint doi: https://doi.org/10.1101/2020.11.18.20233528; this version posted November 20, 2020. The copyright holder for this preprint (which was not certified by peer review) is the author/funder, who has granted medRxiv a license to display the preprint in perpetuity.

It is made available under a CC-BY-NC-ND 4.0 International license .
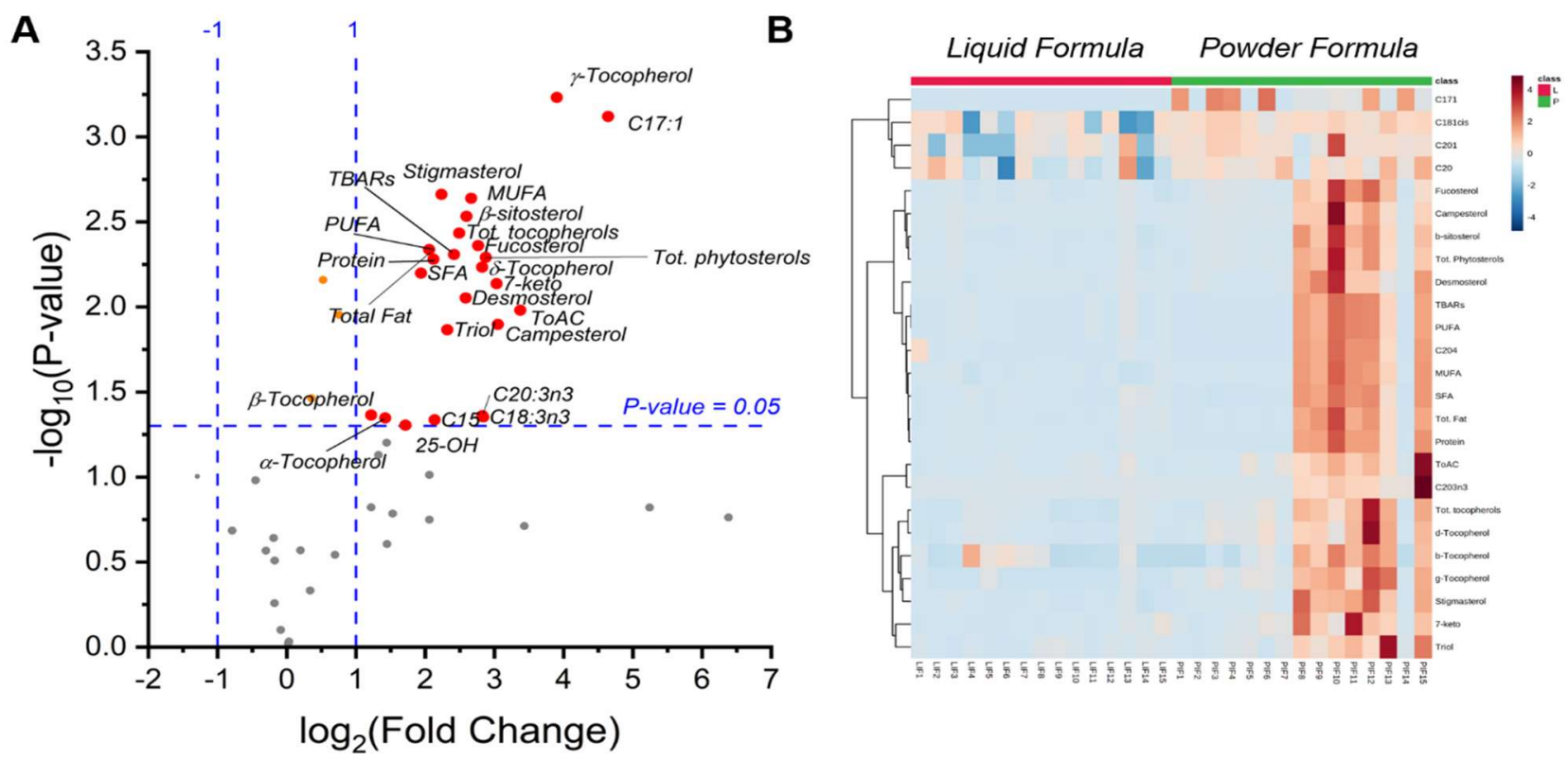

Figure 1. Metabolomic signature of powder (PIF) vs liquid (LIF) infant formulas. A) Volcano plot showing significant contrast between PIF and LIF. Compounds or classes of compounds with $>2$-fold higher amount per serving in PIF at $\mathrm{p}=0.05$ are depicted with red dots. B) ANOVA heatmap, showing significant differences between IF $(\mathrm{p}<0.05)$.

TBARS and ToAC values are also difficult to compare with literature, given the measurement units adopted. For TBARs, we found an average of $0.52 \mathrm{ppb}(0.49-0.55 \mathrm{ppb}, 95 \%$ CI), which is comparable only with the amount found by Turoli et al. (Turoli, Testolin, Zanini, \& Bellù, 2004) and Michaski et al. (Michalski, Calzada, Makino, Michaud, \& Guichardant, 2008). Other reports have inconsistently high values $>100 \mathrm{ppb}$ (Cesa, 2004). ToAC, measured as ascorbic acid equivalents, is a direct estimation of the overall antioxidant capacity (Boatright \& Crum, 2016). In our dataset, we have an average of $7.4 \mathrm{mg} / \mathrm{mL}(4.3-10.6 \mathrm{mg} / \mathrm{mL})$; however, LIF had roughly double the amount that PIF.

Load of steroids and cholesterol oxidative products in IFs. Several non-oxidative and oxidative markers characterize the powder formulation. The Volcano plot for the lipidomics markers quantified in the present study is depicted in Figure 1. Among non-oxidative markers, PIF has higher amounts of phytosterols, including tocopherols, fucosterol, and campesterol. Tocopherols are supplemented in formulas (Martysiak-Zurowska et al., 2013; Miquel et al., 2004), 
medRxiv preprint doi: https://doi.org/10.1101/2020.11.18.20233528; this version posted November 20, 2020. The copyright holder for this preprint (which was not certified by peer review) is the author/funder, who has granted medRxiv a license to display the preprint in perpetuity.

It is made available under a CC-BY-NC-ND 4.0 International license .

or derived from the vegetable oils used for their formulation (Manglano et al., 2005) for increasing the antioxidant capacity and prevent lipid peroxidation and thus reduce oxidative stress (Jialal, Devaraj, \& Venugopal, 2002). Phytosterols also are derived from the vegetable oils used for formula preparation. Some phytosterols are naturally present in breast milk, as campesterol, while fucosterol is not usually found in human milk (Hamdan et al., 2018). Among oxidative markers, the powder IF has several folds larger amounts of individual COPs (7-keto, triol, and 25-OH), as well as MDA content. It is worth to note that 7-keto is an end-product of cholesterol oxidation and is derived from further oxidation of 7-hydroxyl epimers. Similarly, triol is the end-product of 5,6epoxides, and $25-\mathrm{OH}$ is the most important derivative of cholesterol oxidation in its side chain (Medina-Meza, Rodriguez-Estrada, Garcia, \& Lercker, 2012; Medina-Meza, Rodríguez-Estrada, García, \& Lercker, 2012; Medina-Meza, Rodriguez-Estrada, Lercker, Barnaba, \& García, 2014)

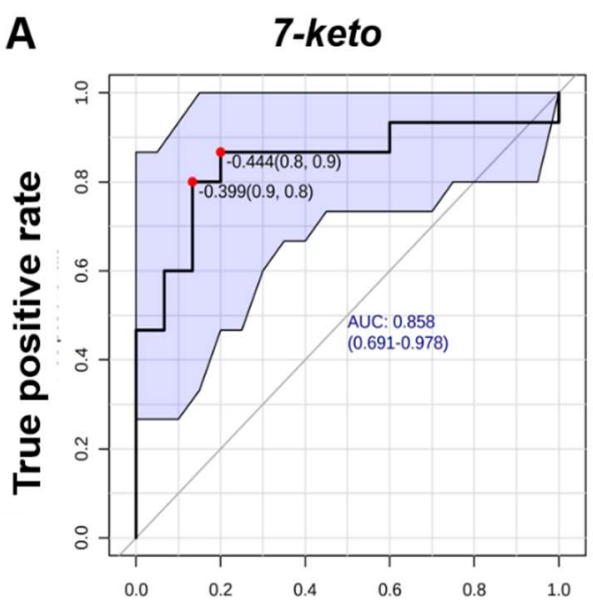

False positive rate
B

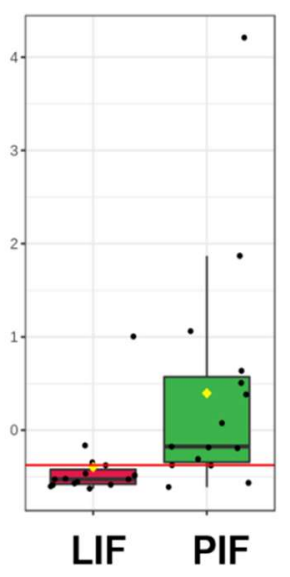

The ANOVA-based heatmap in

Figure 1B is helpful to identify characteristics of abundance that are predominant in the powder vs. liquid presentation. At the same time, Figure 1B suggests a potential subclassification based on a more specific lipid and oxidative

Figure 2. 7-keto as potential biomarker for IF processing. A) ROC curve for 7-keto. B) Boxplot of 7-keto. The notch indicates $95 \% \mathrm{CI}$ around the median of each group. The yellow diamond indicates the mean concentration for each group.

signature. Strikingly, $\mathrm{a}$ subpopulation of PIFs showed

higher content in several COPs, which potentially masks the fact that only 7-keto and triol are spiking in the Volcano plot. 
medRxiv preprint doi: https://doi.org/10.1101/2020.11.18.20233528; this version posted November 20, 2020. The copyright holder for this preprint (which was not certified by peer review) is the author/funder, who has granted medRxiv a license to display the preprint in perpetuity.

It is made available under a CC-BY-NC-ND 4.0 International license .

A

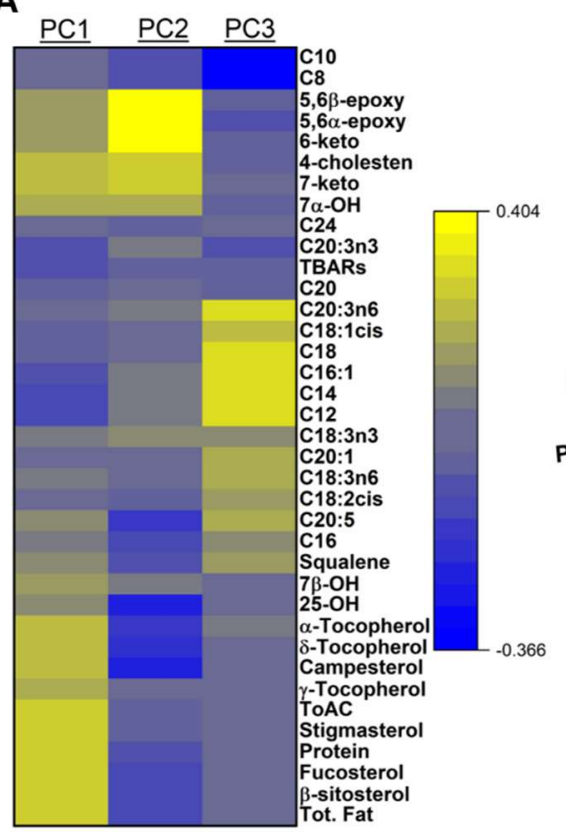

B

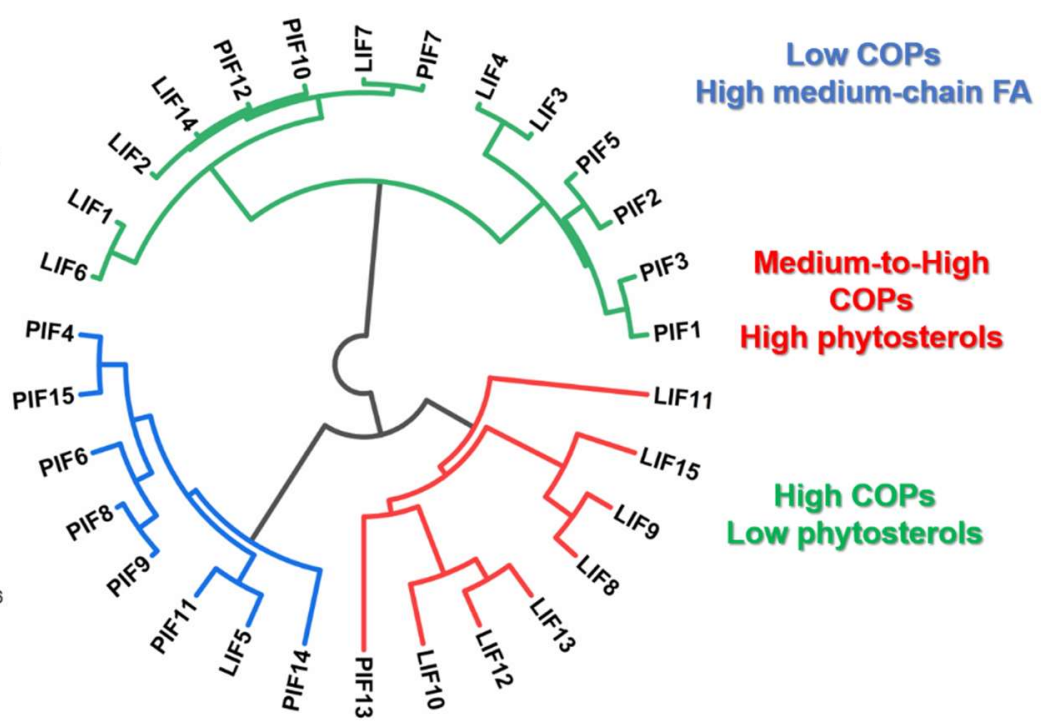

Figure 3. Re-classification of IFs using multivariate data analysis and hierarchical clustering. A) Heat-map representing the metabolomics variables and their scores associated with the PCs. B) Dendrogram depicting the classification of IFs according to the PCA variables.

Biomarker of the oxidative process. Next, we performed a ROC analysis to identify potential biomarkers as a signature of formula manufacturing. $\gamma$-tocopherol followed by campesterol gave higher AUC values $(>0.95, p<0.001)$; however, they are not indicative of the process per se, but the ingredients used for formulation. On the other hand, COPs and the oxidative load are a direct consequence of the food process history (Savage, Dutta, \& Rodriguez-Estrada, 2002; Tamanna \& Mahmood, 2015). In the biomarker analysis, 7-keto showed good discriminant potential $(\mathrm{AUC}=0.86, p<0.01)$ (Fig. 2A,B), which was also evident from the $t$-test (Table 1). For instance, 7-keto is a direct derivative of cholesterol autooxidation, which is exacerbated during food processing, particularly those operations that include heat, as thermal sterilization (RodriguezEstrada et al., 2014; Zardetto, Barbanti, \& Rosa, 2014).

Reclassification of infant formulas based on metabolite fingerprint. The heatmap presented in Fig. 1B hints at a subclassification based on metabolite fingerprint rather than 
medRxiv preprint doi: https://doi.org/10.1101/2020.11.18.20233528; this version posted November 20, 2020. The copyright holder for this preprint (which was not certified by peer review) is the author/funder, who has granted medRxiv a license to display the preprint in perpetuity.

It is made available under a CC-BY-NC-ND 4.0 International license .

commercial presentation. Thus, we performed a PCA-based factor analysis followed by hierarchical classification to re-group the IF based on selected variables explaining the majority of variance across metabolic responses. PCA reduces the dimensionality of the data set; each principal component represents a new variable in which the original metabolite responses have a "weight" (Figure 3A). The first three principal components retained $>60 \%$ variance and were retained for further statistical assessment (Figure 3A). Based on the score of each IF, three groups were identified (Figure 3B): i) IFs having highest COPs content, with low phytosterols and tocopherols; this group is also characterized for having low ToAC. Members of this group (green in the dendrogram) are equally distributed among PIF and LIF; ii) IFs having higher PC1 scores, corresponding with high phytosterols amount and moderate-to-high oxidative load (COPs), including the cytotoxic 5,6-epoxides epimers, 6-keto, and 7-keto. This group (red in Figure 3B) consists of the great majority of LIF formulas ( 7 of 8 total). Finally, iii) IFs with the lowest load in autooxidation products of cholesterol. The third group (blue in the dendrogram) is more heterogeneous, it mainly contains PIF.

Dietary intake of 7-keto, COPs, sterols, and phytosterols. Infants consume milk, either breast milk or formulations, as the only food intake for the first 6 months of their life (Harris \& Pomeranz, 2020). After 6 months, and coinciding with weaning, milk is integrated with solid food. We estimated the dietary intake for total COPs, total animal sterols, total phytosterols, and our identified biomarker 7-keto (Fig. 4) over the first year of infant life. Overall, the daily intake decreases by half once weaning sets in; after six months, the dietary intake does not reflect the exposure to these compounds, since we are not taking into account sterols and oxidative derivatives present in solid foods. Compared to phytosterols, there is higher variability in COPs, sterols, and 
medRxiv preprint doi: https://doi.org/10.1101/2020.11.18.20233528; this version posted November 20, 2020. The copyright holder for this preprint (which was not certified by peer review) is the author/funder, who has granted medRxiv a license to display the preprint in perpetuity.

It is made available under a CC-BY-NC-ND 4.0 International license .

7-keto intakes, given the broad distributions in our IF dataset. The dietary intake of phytosterols is roughly double than animal sterols (Fig. 4B,C).

\section{Discussion}

Diet plays a critical role not only in infants' growth, body composition, and development of the immune system, but also in the potential risk of developing metabolic disorders and obesity in adulthood (Lemaire, Le Huerou-Luron, \& Blat, 2018). IFs provide nourishment at both macroand micronutrient levels (Fuglestad et al., 2017), and although pediatric recommendations do not lean towards one formulation or another, as from the present study PIF and LIF have different macronutrient constituents. Powdered IF is put through manufacturing steps such as mixing, evaporation, and spray drying. PIF is usually stored in an aluminum can and vacuum sealed with nitrogen until the consumer first opens it (Jiang \& Guo, 2014). Liquid IF can be either concentrated (needs to be mixed with water before consumption) or ready-to-fed and usually sterilization with high temperatures, followed by aseptic packaging are applied to guarantee microbial safety. In PIF, the high load in oxidized sterols and MDA hints a potential cause in the process of manufacturing. The LIFs undergo ultra-high temperature pasteurization at temperatures around $135-150^{\circ} \mathrm{C}$ for less than 2.5 seconds, the IF is heated between $85^{\circ} \mathrm{C}$ and $120^{\circ} \mathrm{C}$ to emulsify the water and oil phases. Then the $\mathrm{pH}$ is adjusted, and some minor ingredients are added, while the PIF is spray dried using air at $170-250^{\circ} \mathrm{C}$ with a product temperature $>100^{\circ} \mathrm{C}$ for longer times. Spray drying equipment can also provide indirect or direct heating, combined with low NOx (nitrogen oxides) or high NOx in the combustion gases which may affect the formation of oxidized derivatives (Chan et al., 1993). In addition, glass bottles, metal cans, polypropylene bottles, or 
medRxiv preprint doi: https://doi.org/10.1101/2020.11.18.20233528; this version posted November 20, 2020. The copyright holder for this preprint (which was not certified by peer review) is the author/funder, who has granted medRxiv a license to display the preprint in perpetuity.

It is made available under a CC-BY-NC-ND 4.0 International license .
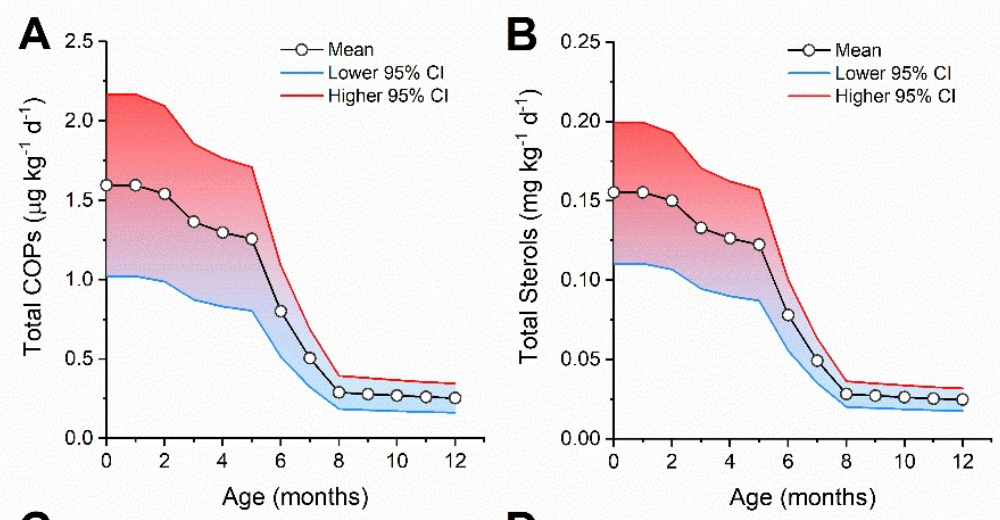

cardboard with layers of
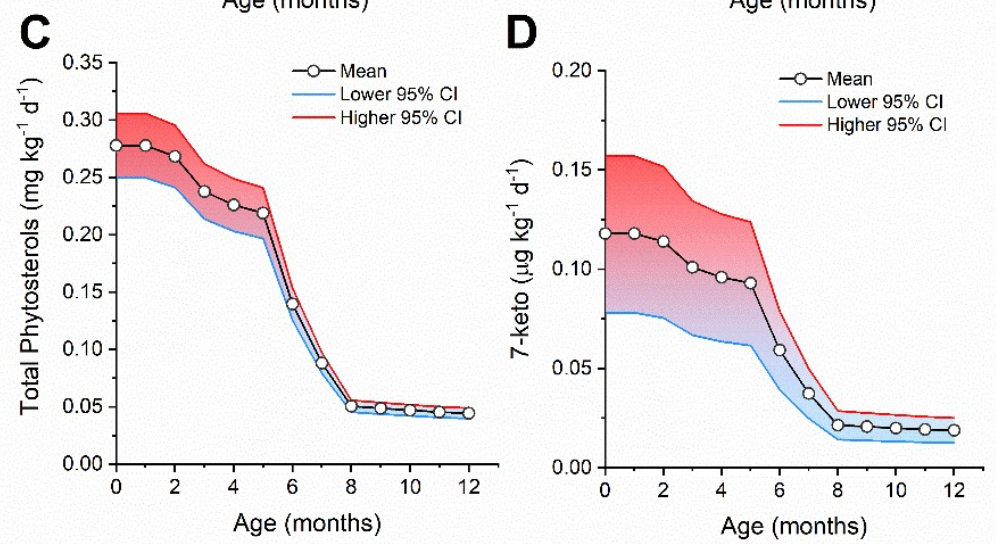

Figure 4. Dietary intake estimation for A) total COPs, B) total sterols, C) total phytosterols, and D) 7-keto during the first year of infant development.

polypropylene and aluminum

foil are some materials

commonly used for packaging

of IF and their impact on the oxidative status is still under investigation (Guo, 2014).

It is well known that heat is one of the major triggers of lipid and cholesterol peroxidation (K. Al-Ismail, 2002; K. M. Al-Ismail, Herzallah, \& Humied, 2007; Beltran, Pla, Capellas, Yuste, \& Mor-Mur, 2004; Li et al., 1996; Mazalli \& Bragagnolo, 2009; Medina-Meza, Rodriguez-Estrada, Lercker, Soto-Rodriguez, \& Garcia, 2011; Smith, 1996). However, it is worth noting that the oxidative load is balanced by a higher antioxidant capacity due to the supplementation of antioxidants, particularly tocopherols. The balance between cholesterol and phytosterol intake is critical for infant development. Breast milk has $0.10-0.15 \mathrm{mg} / \mathrm{mL}$ of cholesterol, whereas cowmilk based infant formulas $0.01-0.04 \mathrm{mg} / \mathrm{mL}$, meaning that infants alimented with milk formulation have less cholesterol intake (Wagner \& von Stockhausen, 1988). Since the late '70s, it was known that milk formulas enriched with vegetable oils cause reduction of plasma cholesterol and LDL, with a concurrent increase of plasma and tissue phytosterols (M. Mellies, Glueck, C. J., 
medRxiv preprint doi: https://doi.org/10.1101/2020.11.18.20233528; this version posted November 20, 2020. The copyright holder for this preprint (which was not certified by peer review) is the author/funder, who has granted medRxiv a license to display the preprint in perpetuity.

It is made available under a CC-BY-NC-ND 4.0 International license .

Sweeney, C., Fallat, R. W., Tsang, R. C., Ishikawa, T. T., 1976; M. J. Mellies, Ishikawa, T. T., Glueck, C. J., Bove, K., Morrison, J., 1976). For instance, infants suffering sitosterolemia have increased absorption of phytosterols and cholesterol, causing accelerated atherosclerosis (Yoo, 2016). Higher intake of phytosterols is clearly associated with parenteral nutrition-associated liver disease (Kurvinen et al., 2012), which can be irreversible and devastating for infants (Teitelbaum \& Tracy, 2001). A recent work on absorption kinetics, showed that neonates rapidly accumulate sitosterol and campesterol when supplied with soybean oil lipids (Nghiem-Rao et al., 2015). Thus, our large database could support further clinical studies and personalized nutrition for individuals possessing genetic deficiencies that lead to uncontrolled sterols accumulation.

LIFs contain higher amounts of COPs, although differences in individual COPs were not significant (Table 1) given the broad distribution across samples. However, 7-keto was significantly higher in PIF $(\mathrm{p}<0.01)$, thus we propose this compound as a potential biomarker of formula processing. 7-keto was already proposed as a biomarker of cholesterol oxidation in food matrices (Rodriguez-Estrada et al., 2014). Dehydrated products as milk powder seem to be particularly susceptible to generate 7-keto from cholesterol autoxidation (Sieber, 2005), which is possibly due to the high temperature that favors the conversion from both 5,6-epoxides epimers and 7-hydroxy precursors (Nourooz-Zadeh \& Appelqvist, 1988). 7-keto is one of the most studied COPs, due to several biological effects reported either in cell or animal studies. Regarding infants, 7-keto is a biomarker for the early detection of inherited disorders related to cholesterol metabolism, including Niemann-Pick Type C disease and acid sphingomyelinase disease (Boenzi et al., 2016; Lin et al., 2014). Thus, it is important to know that formula intake can possibly result in an increase of 7-keto plasma concentration; however, we are far from understanding the rate and extent of COPs adsorption in infants. 
medRxiv preprint doi: https://doi.org/10.1101/2020.11.18.20233528; this version posted November 20, 2020. The copyright holder for this

It is made available under a CC-BY-NC-ND 4.0 International license .

Finally, our study allowed a re-classification of the IF based on the metabolite signature, rather than label information (Figure 3). Three groups emerged, having dominant determinants of COPs and phytosterol contents. We are aware that this classification is not exhaustive since it takes into consideration only lipid and steroid molecules. However, it is a starting point for further studies targeted to expand our knowledge in food composition, towards a data-driven approach for personalized nutrition.

\section{Conclusions}

IF are a useful alternative to breast milk; however, the effects of ultra-processing, such as high temperatures may impact the redox balance (antioxidant vs. oxidant load), significantly affecting their nutritional quality. The balance between cholesterol and phytosterols should be evaluated pre and post-processing) to avoid oxidized products and ensure optimal cholesterol absorption on infant's diet, which is vital during the first months of life. In addition, the nutritional quality of IF may be compromised if the microbial reduction is the only standard for ensuring food safety. Lipids and proteins are thermally sensitive molecules which may generate hundreds of oxidized derivatives, harmful to human health. Enhancing the manufacturing processes, especially for PIF, should be implemented to reduce the generation of oxidized compounds. More effective and stable antioxidants should also be added to lower the potential for oxidation. The redox balance (e.g., ToAC vs TBARs) of the final product should be a critical parameter to be evaluated as a hallmark of the overall nutritional quality of IF. In addition, the study of oxidized derivatives interaction with the gut microbiome is needed, especially on infants where the gut is not fully developed.

\section{Acknowledgements}


medRxiv preprint doi: https://doi.org/10.1101/2020.11.18.20233528; this version posted November 20, 2020. The copyright holder for this preprint (which was not certified by peer review) is the author/funder, who has granted medRxiv a license to display the preprint in perpetuity. It is made available under a CC-BY-NC-ND 4.0 International license .

This study has been funded by SHORA Spectrum Health through the grant RC108332 and the USDA National Institute of Food and Agriculture, Hatch project MICL02526 to Alice Kilvington, and Michigan State University start-up funding to I.G.M.M. Many thanks to Karen Ferguson RD, CSP, Pediatric Intensive Care Unit \& Pediatric Burn Service, Helen DeVos Children's Hospital for her support and guidance. 


\section{References:}

Abela, G. S., Leja, M., Janoudi, A., Perry, D., Richard, J., De Feijter-Rupp, H., . . Meza, I. M. (2019). RELATIONSHIP BETWEEN ATHEROSCLEROSIS AND CERTAIN SOLID CANCER TUMORS. Journal of the American College of Cardiology, 73(9 Supplement 1), 156. doi:10.1016/s0735-1097(19)30764-8

Al-Ismail, K. (2002). Effect of two methods of grilling on the oxidative rancidity and cholesterol oxidation in beef and chicken shawerma. Grasas Y Aceites, 53(3), 335-339.

Al-Ismail, K. M., Herzallah, S. M., \& Humied, M. A. (2007). Effect of processing and storage of Jameed on conjugated linoleic acid content and fat and cholesterol oxidation. LWT - Food Science and Technology, 40(3), 454-459. doi:10.1016/j.lwt.2006.02.001

Babawale, E. A., Jones, P. J. H., Mercer, K. E., Lin, H. X., Yeruva, L., Bar Yoseph, F., \& Rutherfurd, S. M. (2018). Modulating Sterol Concentrations in Infant Formula Influences Cholesterol Absorption and Synthesis in the Neonatal Piglet. Nutrients, 10(12). doi:10.3390/nu10121848

Beltran, E., Pla, R., Capellas, M., Yuste, J., \& Mor-Mur, M. (2004). Lipid oxidation and colour in pressure- and heat-treated minced chicken thighs. Journal of the Science of Food and Agriculture, 84(11), 1285-1289. doi:10.1002/jsfa.1778

Boatright, W. L., \& Crum, A. D. (2016). Redox cycling and generation of reactive oxygen species in commercial infant formulas. Food chemistry, 196, 189-195.

Boenzi, S., Deodato, F., Taurisano, R., Goffredo, B. M., Rizzo, C., \& Dionisi-Vici, C. (2016). Evaluation of plasma cholestane-3 $\beta, 5 \alpha, 6 \beta$-triol and 7-ketocholesterol in inherited disorders related to cholesterol metabolism. Journal of lipid research, 57(3), 361-367.

Botsoglou, N. A., Fletouris, D. J., Papageorgiou, G. E., Vassilopoulos, V. N., Mantis, A. J., \& Trakatellis, A. G. (1994). RAPID, SENSITIVE, AND SPECIFIC THIOBARBITURIC ACID METHOD FOR MEASURING LIPID-PEROXIDATION IN ANIMAL TISSUE, FOOD, AND FEEDSTUFF SAMPLES. Journal of Agricultural and Food Chemistry, 42(9), 1931-1937. doi:10.1021/jf00045a019

Cadima, J., \& Jolliffe, I. T. (1995). Loading and correlations in the interpretation of principle compenents. Journal of Applied Statistics, 22(2), 203-214.

Calderon-Santiago, M., Peralbo-Molina, A., Priego-Capote, F., \& de Castro, M. D. L. (2012). Cholesterol oxidation products in milk: Processing formation and determination. European Journal of Lipid Science and Technology, 114(6), 687-694. doi:10.1002/ejlt.201100139

Ceballos, L. S., Morales, E. R., Adarve, G. D. T., Castro, J. D., Martinez, L. P., \& Sampelayo, M. R. S. (2009). Composition of goat and cow milk produced under similar conditions and analyzed by identical methodology. Journal of Food Composition and Analysis, 22(4), 322-329. doi:10.1016/j.jfca.2008.10.020

Cesa, S. (2004). Malondialdehyde contents in infant milk formulas. Journal of Agricultural and Food Chemistry, 52(7), 2119-2122. doi:10.1021/jf0344461

Chan, S.-H., Gray, J. I., Gomaa, E. A., Harte, B. R., Kelly, P. M., \& Buckley, D. J. (1993). Cholesterol oxidation in whole milk powders as influenced by processing and packaging. Food Chemistry, 47(4), 321-328.

Chen, Y.-S., Aluwi, N. A., Saunders, S. R., Ganjyal, G. M., \& Medina-Meza, I. G. (2019). Metabolic fingerprinting unveils quinoa oil as a source of bioactive phytochemicals. Food Chemistry. 
Choi, Y. Y., Ludwig, A., Andreyeva, T., \& Harris, J. L. (2020). Effects of United States WIC infant formula contracts on brand sales of infant formula and toddler milks. Journal of Public Health Policy, 41(3), 303-320. doi:10.1057/s41271-020-00228-z

Chong, J., Soufan, O., Li, C., Caraus, I., Li, S., Bourque, G., . . Xia, J. (2018). MetaboAnalyst 4.0: towards more transparent and integrative metabolomics analysis. Nucleic acids research, 46(W1), W486-W494.

De Onis, M., \& Onyango, A. W. (2008). WHO child growth standards. Lancet, 371(9608), 204204.

Folch, J., Lees, M., \& Sloane-Stanley, G. (1957). A simple method for the isolation and purification of total lipids from animal tissues. J biol Chem, 226(1), 497-509.

Food and Agriculture Organization, U. N. U. a. W. H. O. (2004). Human Energy Requirements: Report of a Joint FAO/WHO/UNU Expert Consultation: Rome, 17-24 October 2001 (Vol. 1): Food \& Agriculture Org.

Fuglestad, A., Demerath, E. W., Finsaas, M., Moore, C., Georgieff, M. K., \& Carlson, S. M. (2017). Maternal executive function, infant feeding responsiveness and infant growth during the first 3 months. Pediatric obesity, 12, 102-110.

García-Llatas, G., Cercaci, L., Rodriguez-Estrada, M. T., Lagarda, M. J., Farré, R., \& Lercker, G. (2008). Sterol oxidation in ready-to-eat infant foods during storage. J Agric Food Chem, 56(2), 469-475. doi:10.1021/jf072475g

García-Llatas, G., Cercaci, L., Rodriguez-Estrada, M. T., Lagarda, M. J., Farré, R., \& Lercker, G. (2008). Sterol oxidation in ready-to-eat infant foods during storage. Journal of agricultural and food chemistry, 56(2), 469-475.

Garofalo, R. (2010). Cytokines in human milk. The Journal of pediatrics, 156(2), S36-S40.

Georgieff, M., \& Rao, R. (2001). The role of nutrition in cognitive development. Handbook of developmental cognitive neuroscience, 491-504.

Gil, A., \& Valverde, L. (1985). Nucleotide enriched humanized milk and process for its preparation. In: Google Patents.

Gorassini, A., Verardo, G., Fregolent, S. C., \& Bortolomeazzi, R. (2017). Rapid determination of cholesterol oxidation products in milk powder based products by reversed phase SPE and HPLC-APCI-MS/MS. Food Chem, 230, 604-610. doi:10.1016/j.foodchem.2017.03.080

Grandgirard, A., Sergiel, J. P., Nour, M., Demaison-Meloche, J., \& Gihiès, C. (1999). Lymphatic absorption of phytosterol oxides in rats. Lipids, 34(6), 563-570.

Griffiths, W. J., Abdel-Khalik, J., Hearn, T., Yutuc, E., Morgan, A. H., \& Wang, Y. Q. (2016). Current trends in oxysterol research. Biochemical Society Transactions, 44, 652-658. doi:10.1042/bst20150255

Group., C. D. T. (1991). Dexamethasone therapy in neonatal chronic lung disease: an international placebo-controlled trial. Pediatrics, 88, 421-427.

Guardiola, F., Bou, R., Boatella, J., \& Codony, R. (2004). Analysis of sterol oxidation products in foods. Journal of Aoac International, 87(2), 441-466.

Guo, Y. J. J. M. (2014). Processing technology for infant formula. In W. publishing (Ed.), Human Milk Biochemistry and Infant Formula Manufacturing Technology.

Hageman, J. H., Danielsen, M., Nieuwenhuizen, A. G., Feitsma, A. L., \& Dalsgaard, T. K. (2019). Comparison of bovine milk fat and vegetable fat for infant formula: Implications for infant health. International dairy journal, 92, 37-49. 
Hamdan, I. J., Sanchez-Siles, L. M., Garcia-Llatas, G., \& Lagarda, M. a. J. s. (2018). Sterols in infant formulas: a bioaccessibility study. Journal of agricultural and food chemistry, 66(6), 1377-1385.

Harris, J. L., \& Pomeranz, J. L. (2020). Infant formula and toddler milk marketing: opportunities to address harmful practices and improve young children's diets. Nutrition Reviews.

Hassiotou, F., Hepworth, A. R., Metzger, P., Lai, C. T., Trengove, N., Hartmann, P. E., \& Filgueira, L. (2013). Maternal and infant infections stimulate a rapid leukocyte response in breastmilk. Clinical \& Translational Immunology, 2. doi:10.1038/cti.2013.1

Horta, B. L., Victora, C. G., \& Organization, W. H. (2013). Short-term effects of breastfeeding: a systematic review on the benefits of breastfeeding on diarrhoea and pneumonia mortality.

Howie, P. W., Forsyth, J. S., Ogston, S. A., Clark, A., \& Florey, C. D. (1990). Protective effect of breast feeding against infection. British Medical Journal, 300(6716), 11-16. doi:10.1136/bmj.300.6716.11

Jialal, I., Devaraj, S., \& Venugopal, S. K. (2002). Oxidative stress, inflammation, and diabetic vasculopathies: The role of alpha tocopherol therapy. Free Radical Research, 36(12), 1331-1336. doi:10.1080/1071576021000038531

Jiang, Y. J., \& Guo, M. (2014). 8 - Processing technology for infant formula. In Human Milk Biochemistry and Infant Formula Manufacturing Technology (pp. 211-229): Woodhead Publishing.

Kaiser, H. F. (1974). An index of factorial simplicity. Psychometrika, 39(1), 31-36.

Khan, I. T., Nadeem, M., Imran, M., Ayaz, M., Ajmal, M., Ellahi, M. Y., \& Khalique, A. (2017). Antioxidant capacity and fatty acids characterization of heat treated cow and buffalo milk. Lipids in Health and Disease, 16. doi:10.1186/s12944-017-0553-z

Kilvington, A., Maldonado-Pereira, L., Torres-Palacios, C., \& Medina-Meza, I. (2019). Phytosterols and their oxidative products in infant formula. Journal of Food Process Engineering, e13151.

Koletzko, B., Kries, R.D., Closa, R., Escribano, J., Scaglioni., Giovannini, M., Beyer J., Demmelmain, H., Gruzfeld, D., Dobrzanska, A., Sengier, A., Langhendries, J.P., Rolland Cachera, M.F., Grote, V. (2009). Lower protein in infant formula is associated with lower weight up to age $2 \mathrm{y}$ : a randomized clinical trial. The American journal of clinical nutrition, 89(6), 1836-1845.

Kulig, W., Cwiklik, L., Jurkiewicz, P., Rog, T., \& Vattulainen, I. (2016). Cholesterol oxidation products and their biological importance. Chem Phys Lipids, 199, 144-160. doi:10.1016/j.chemphyslip.2016.03.001

Kurvinen, A., Nissinen, M. J., Andersson, S., Korhonen, P., Ruuska, T., Taimisto, M., . . . Arikoski, P. (2012). Parenteral plant sterols and intestinal failure-associated liver disease in neonates. Journal of pediatric gastroenterology and nutrition, 54(6), 803-811.

Lacroix, J., Infanterivard, C., Gauthier, M., Rousseau, E., \& Vandoesburg, N. (1986). Upper gastrointestinal- tract bleeding acquired in a pediatric intensive care unit prophylaxis trial with cimetidine. Journal of Pediatrics, 108(6), 1015-1018. doi:10.1016/s00223476(86)80952-0

Laurens, M. L. L., Jaji, A. M., Montgomery, J., Jess, J., Ferguson, K., Parker, J., . . Rajasekaran, S. (2020). Preadmission Diet and Zip Code Influences the Pediatric Critical Care Clinical Course for Infants with Severe Respiratory Illness $(\mathrm{N}=187)$. Journal of Pediatric Intensive Care. 
Laurens, M. L. L., Kraus-Friedberg, C., Kar, W., Sanfilippo, D., Rajasekaran, S., Comstock, S. S. (2020). Dietary Intake Influences Metabolites in Healthy Infants: A Scoping Review. Nutrients, 12(7). doi:10.3390/nu12072073

Lee, J., Jang, E. S., \& Kim, B. (2013). Development of isotope dilution-liquid chromatography/mass spectrometry combined with standard addition techniques for the accurate determination of tocopherols in infant formula. Analytica Chimica Acta, 787, 132-139. doi:10.1016/j.aca.2013.05.034

Lemaire, M., Le Huerou-Luron, I., \& Blat, S. (2018). Effects of infant formula composition on long-term metabolic health. Journal of Developmental Origins of Health and Disease, 9(6), 573-589. doi:10.1017/s2040174417000964

Li, S. X., Cherian, G., Ahn, D. U., Hardin, R. T., \& Sim, J. S. (1996). Storage, Heating, and Tocopherols Affect Cholesterol Oxide Formation in Food Oils. Journal of Agricultural and Food Chemistry, 44(12), 3830-3834. doi:10.1021/jf950732o

Liang, Y. T., Wong, W. T., Guan, L., Tian, X. Y., Ma, K. Y., Huang, Y., \& Chen, Z. Y. (2011). Effect of phytosterols and their oxidation products on lipoprotein profiles and vascular function in hamster fed a high cholesterol diet. Atherosclerosis, 219(1), 124-133. doi:10.1016/j.atherosclerosis.2011.06.004

Lin, N., Zhang, H., Qiu, W., Ye, J., Han, L., Wang, Y., \& Gu, X. (2014). Determination of 7ketocholesterol in plasma by LC-MS for rapid diagnosis of acid SMase-deficient Niemann-Pick disease. Journal of lipid research, 55(2), 338-343.

Lorenzo, I. S., Tonato, A. M. C., Puentes, A. D., Nieto, A., Herrmann, F., Dieguez, E., . . . Campoy, C. (2019). The Effect of an Infant Formula Supplemented with AA and DHA on Fatty Acid Levels of Infants with Different FADS Genotypes: The COGNIS Study. Nutrients, 11(3). doi:10.3390/nu11030602

Maldonado, J., Gil, A., Narbona, E., \& Molina, J. A. (1998). Special formulas in infant nutrition: a review. Early human development, 53, S23-S32.

Maldonado-Pereira, L., Schweiss, M., Barnaba, C., \& Medina-Meza, I. G. (2018). The role of cholesterol oxidation products in food toxicity. Food and Chemical Toxicology, 118, 908939.

Manglano, P., Lagarda, M. J., Silvestre, M. D., Vidal, C., Clemente, G., \& Farre, R. (2005). Stability of the lipid fraction of milk-based infant formulas during storage. European Journal of Lipid Science and Technology, 107(11), 815-823. doi:10.1002/ejlt.200501172

Martin, C. R., Ling, P. R., \& Blackburn, G. L. (2016). Review of Infant Feeding: Key Features of Breast Milk and Infant Formula. Nutrients, 8(5). doi:10.3390/nu8050279

Martysiak-Zurowska, D., Szlagatys-Sidorkiewicz, A., \& Zagierski, M. (2013). Concentrations of alpha- and gamma-tocopherols in human breast milk during the first months of lactation and in infant formulas. Maternal and Child Nutrition, 9(4), 473-482. doi:10.1111/j.17408709.2012.00401.x

Mazalli, M. R., \& Bragagnolo, N. (2009). Increase of cholesterol oxidation and decrease of PUFA as a result of thermal processing and storage in eggs enriched with n-3 fatty acids. J Agric Food Chem, 57(11), 5028-5034. doi:10.1021/jf901187j

Medina-Meza, I. G., \& Barnaba, C. (2013). Kinetics of cholesterol oxidation in model systems and foods: current status. Food Engineering Reviews, 5(3), 171-184.

Medina-Meza, I. G., Rodriguez-Estrada, M. T., Garcia, H. S., \& Lercker, G. (2012). Oxidative Pattern from Fluorescent Light Exposition of Crystalline Cholesterol. Food Biophysics, 7(3), 209-219. doi:10.1007/s11483-012-9259-y 
Medina-Meza, I. G., Rodriguez-Estrada, M. T., Lercker, G., Soto-Rodriguez, I., \& Garcia, H. S. (2011). UNUSUAL OXIDATIVE PATTERN IN THERMO-OXIDATION OF DRY FILMS OF CHOLESTEROL. Revista Mexicana De Ingenieria Quimica, 10(1), 47-57.

Medina-Meza, I. G., Rodríguez-Estrada, M. T., García, H. S., \& Lercker, G. (2012). Oxidative Pattern from Fluorescent Light Exposition of Crystalline Cholesterol. Food Biophysics, 7(3), 209-219. doi:10.1007/s11483-012-9259-y

Medina-Meza, I. G., Rodriguez-Estrada, M. T., Lercker, G., Barnaba, C., \& García, H. S. (2014). Kinetics of 25-hydroperoxycholesterol formation during photo-oxidation of crystalline cholesterol. Journal of the science of food and agriculture, 94(8), 1543-1551.

Mellies, M., Glueck, C. J., Sweeney, C., Fallat, R. W., Tsang, R. C., Ishikawa, T. T. (1976). Plasma and dietary phytosterols in children. Pediatrics, 57(1), 60-67.

Mellies, M. J., Ishikawa, T. T., Glueck, C. J., Bove, K., Morrison, J. (1976). Phytosterols in aortic tissue in adults and infants. J Lab Clin Med, 88(6), 914-921.

Michalski, M. C., Calzada, C., Makino, A., Michaud, S., \& Guichardant, M. (2008). Oxidation products of polyunsaturated fatty acids in infant formulas compared to human milk-a preliminary study. Molecular nutrition \& food research, 52(12), 1478-1485.

Miller, D. D. (1998). Food chemistry: A laboratory manual: Wiley New York.

Miquel, E., Alegria, A., Barbera, R., Farre, R., \& Clemente, G. (2004). Stability of tocopherols in adapted milk-based infant formulas during storage. International Dairy Journal, 14(11), 1003-1011. doi:10.1016/j.idairyj.2004.04.002

Monteiro, C. A., Cannon, G., Levy, R. B., Moubarac, J. C., Louzada, M. L. C., Rauber, F., . . Jaime, P. C. (2019). Ultra-processed foods: what they are and how to identify them. Public Health Nutrition, 22(5), 936-941. doi:10.1017/s1368980018003762

Nghiem-Rao, T. H., Tunc, I., Mavis, A. M., Cao, Y., Polzin, E. M., Firary, M. F., . . Patel, S. B. (2015). Kinetics of phytosterol metabolism in neonates receiving parenteral nutrition. Pediatric research, 78(2), 181-189.

Nielsen, J. H., Olsen, C. E., Jensen, C., \& Skibsted, L. H. (1996). Cholesterol oxidation in butter and dairy spread during storage. J Dairy Res, 63(1), 159-167.

Nourooz-Zadeh, J., \& Appelqvist, L.-Å. (1988). Cholesterol oxides in Swedish foods and food ingredients: butter and cheese. Journal of the American Oil Chemists' Society, 65(10), 1635-1641.

Ogino, Y., Osada, K., Nakamura, S., Ohta, Y., Kanda, T., \& Sugano, M. (2007). Absorption of dietary cholesterol oxidation products and their downstream metabolic effects are reduced by dietary apple polyphenols. Lipids, 42(2), 151-161. doi:10.1007/s11745-0063008-2

Ouellet, J., Bailey, D., \& Samson, M.-È. (2015). Current opinions on stress-related mucosal disease prevention in Canadian pediatric intensive care units. The Journal of Pediatric Pharmacology and Therapeutics, 20(4), 299-308.

Pozzo, L., Cirrincione, S., Russo, R., Karamac, M., Amarowicz, R., Coscia, A., . . Giribaldi, M. (2019). Comparison of Oxidative Status of Human Milk, Human Milk Fortifiers and Preterm Infant Formulas. Foods, 8(10). doi:10.3390/foods8100458

Rodriguez-Estrada, M. T., Garcia-Llatas, G., \& Lagarda, M. J. (2014). 7-Ketocholesterol as marker of cholesterol oxidation in model and food systems: when and how. Biochem Biophys Res Commun, 446(3), 792-797. doi:10.1016/j.bbrc.2014.02.098 
Romeu-Nadal, M., Chávez-Servín, J. L., Castellote, A. I., Rivero, M., \& López-Sabater, M. C. (2007). Oxidation stability of the lipid fraction in milk powder formulas. Food Chemistry, 100(2), 756-763. doi:10.1016/j.foodchem.2005.10.037

Rossen, L. M., Simon, A. E., \& Herrick, K. A. (2016). Types of Infant Formulas Consumed in the United States. Clinical Pediatrics, 55(3), 278-285. doi:10.1177/0009922815591881

Santana, R. N. S., Santos, V. S., Ribeiro, R. F., Freire, M. S., Menezes, M. A. S., Cipolotti, R., \& Gurgel, R. Q. (2017). Use of ranitidine is associated with infections in newborns hospitalized in a neonatal intensive care unit: a cohort study. Bmc Infectious Diseases, 17. doi:10.1186/s12879-017-2482-x

Savage, G. P., Dutta, P. C., \& Rodriguez-Estrada, M. T. (2002). Cholesterol oxides: their occurrence and methods to prevent their generation in foods. Asia Pacific Journal of Clinical Nutrition, 11(1), 72-78. doi:10.1046/j.1440-6047.2002.00270.x

Saxena, J., Adhikari, B., Brkljaca, R., Huppertz, T., Chandrapala, J., \& Zisu, B. (2019). Physicochemical properties and surface composition of infant formula powders. Food Chemistry, 297. doi:10.1016/j.foodchem.2019.124967

Schött, H.-F., Husche, C., Friedrichs, S., Miller, C. M., McCarthy, F. O., Laufs, U., . . . Lütjohann, D. (2015). 7 $\beta$-Hydroxysitosterol crosses the blood-brain barrier more favored than its substrate sitosterol in ApoE-/- mice. Steroids, 99, 178-182.

Scopesi, F., Zunin, P., Mazzella, M., Testa, M., Boggia, R., Evangelisti, F., \& Serra, G. (2002). 7-ketocholesterol in human and adapted milk formulas. Clin Nutr, 21(5), 379-384.

Sieber, R. (2005). Oxidised cholesterol in milk and dairy products. International Dairy Journal, 15(3), 191-206. doi:10.1016/j.idairyj.2004.07.013

Smith, L. L. (1996). Review of progress in sterol oxidations: 1987-1995. Lipids, 31(5), 453-487. doi:10.1007/bf02522641

Steele, E. M., Baraldi, L. G., Louzada, M. L. D., Moubarac, J. C., Mozaffarian, D., \& Monteiro, C. A. (2016). Ultra-processed foods and added sugars in the US diet: evidence from a nationally representative cross-sectional study. Bmj Open, 6(3). doi:10.1136/bmjopen2015-009892

Sun, C., Zou, X. Q., Yao, Y. P., Jin, J., Xia, Y., Huang, J. H., . . Wang, X. G. (2016). Evaluation of fatty acid composition in commercial infant formulas on the Chinese market: A comparative study based on fat source and stage. International Dairy Journal, 63, 42-51. doi:10.1016/j.idairyj.2016.07.015

Tamanna, N., \& Mahmood, N. (2015). Food processing and maillard reaction products: effect on human health and nutrition. International journal of food science, 2015.

Teitelbaum, D. H., \& Tracy, T. (2001). Parenteral nutrition-associated cholestasis. Paper presented at the Seminars in pediatric surgery.

Testa, G., Rossin, D., Poli, G., Biasi, F., \& Leonarduzzi, G. (2018). Implication of oxysterols in chronic inflammatory human diseases. Biochimie, 153, 220-231.

doi:10.1016/j.biochi.2018.06.006

Traves, D. (2015). Understanding infant formula. Paediatrics and Child Health, 25(9), 413-417.

Turoli, D., Testolin, G., Zanini, R., \& Bellù, R. (2004). Determination of oxidative status in breast and formula milk. Acta paediatrica, 93(12), 1569-1574.

USDA. (2018). USDA Food Composition Databases. Retrieved from https://ndb.nal.usda.gov/ndb/ 
Vine, D. F., Croft, K. D., Beilin, L. J., \& Mamo, J. C. L. (1997). Absorption of dietary cholesterol oxidation products and incorporation into rat lymph chylomicrons. Lipids, 32(8), 887-893. doi:10.1007/s11745-997-0114-0

Wagner, V., \& von Stockhausen, H. (1988). The effect of feeding human milk and adapted milk formulae on serum lipid and lipoprotein levels in young infants. European journal of pediatrics, 147(3), 292-295.

Wang, J., Bertholet, R., Ducret, P., \& Fleith, M. (2000). Lipid composition for infant formula and method of preparation. In: Google Patents.

Wang, M. M., \& Lu, B. Y. (2018). How do oxyphytosterols affect human health? Trends in Food Science \& Technology, 79, 148-159. doi:10.1016/j.tifs.2018.07.002

Wanichthanarak, K., Fan, S., Grapov, D., Barupal, D. K., \& Fiehn, O. (2017). Metabox: A toolbox for metabolomic data analysis, interpretation and integrative exploration. PloS one, $12(1)$, e0171046.

Willinger, T. (2019). Oxysterols in intestinal immunity and inflammation. J Intern Med, 285(4), 367-380. doi:10.1111/joim.12855

Xia, J., \& Wishart, D. S. (2016). Using MetaboAnalyst 3.0 for comprehensive metabolomics data analysis. Current protocols in bioinformatics, 55(1), 14.10. 11-14.10. 91.

Yoo, E.-G. (2016). Sitosterolemia: a review and update of pathophysiology, clinical spectrum, diagnosis, and management. Annals of Pediatric Endocrinology \& Metabolism, 21(1), 7.

Zardetto, S., Barbanti, D., \& Rosa, M. D. (2014). Formation of cholesterol oxidation products (COPs) and loss of cholesterol in fresh egg pasta as a function of thermal treatment processing. Food Research International, 62, 177-182. doi:10.1016/j.foodres.2014.02.028

Zmyslowski, A., \& Szterk, A. (2019). Oxysterols as a biomarker in diseases. Clin Chim Acta, 491, 103-113. doi:10.1016/j.cca.2019.01.022

Zunin, P., Calcagno, C., \& Evangelisti, F. (1998). Sterol oxidation in infant milk formulas and milk cereals. J Dairy Res, 65(4), 591-598. 